\title{
Os trabalhadores com sinais de varíola no acervo da Delegacia Regional do Trabalho do Rio Grande do Sul, 1933-1944
}

\author{
Workers with signs of smallpox in the collection of \\ Regional Office of Labor, Rio Grande do Sul, 1933-1944
}

\section{Aristeu Elisandro Machado Lopes}

Professor, Universidade Federal de Pelotas.

Rua Alberto Rosa, 154

90010-770 - Pelotas - RS - Brasil

aristeuufpel@yahoo.com.br
LOPES, Aristeu Elisandro Machado. Os trabalhadores com sinais de varíola no acervo da Delegacia Regional do Trabalho do Rio Grande do Sul, 19331944. História, Ciências, Saúde - Manguinhos, Rio de Janeiro, v.23, n.4, out.-dez. 2016, p.1209-1227.

\section{Resumo}

A carteira profissional foi criada no Brasil em 1932. Em seguida, surgiram as Inspetorias Regionais do Trabalho, renomeadas, posteriormente, como Delegacias Regionais do Trabalho. No Rio Grande do Sul, a Inspetoria foi instalada em 1933, em Porto Alegre. A logística para a confecção da carteira consistia no preenchimento de uma ficha de qualificação profissional com os dados pessoais e profissionais dos trabalhadores. Um dos campos da ficha se destinava ao registro dos sinais particulares do solicitante, tais como marcas visíveis e falta de membros. Averiguar a presença de um tipo específico de sinal particular é o objetivo deste artigo. Pretende-se trabalhar com as fotografias $3 \times 4$ dos trabalhadores que apresentavam sinais de varíola, bem como com outras informações da ficha.

Palavras-chave: varíola; fotografia; carteira profissional; trabalhadores; Delegacia Regional do Trabalho (DRT).

\section{Abstract}

Work Register Booklet was created in Brazil in 1932. Soon, Regional Labor Inspectorates emerged - after renamed as Regional Office of Labor. In Rio Grande do Sul, this office was settled in 1933 in Porto Alegre. Procedures for making this booklet consisted of filling a professional qualification form with workers' personal and professional information. One of the fields consisted of requester's distinguishing signs, like visible marks and lack of limbs. The purpose of this article is to analyse the presence of one of these distinguishing signs. We use $3 \times 4 \mathrm{~cm}$ photos of workers who presented smallpox signs, as well as other information written in the fields of their forms.

Keywords: smallpox; pictures; work register booklet; workers; Regional Office of Labor. 
$\mathrm{N}^{\circ}$ o dia 21 de março de 1932, o chefe do governo provisório da República, Getúlio Vargas, assinou o decreto que instituía a carteira profissional como documento para o registro da vida laboral dos trabalhadores brasileiros. De documento não obrigatório, passou a ser indispensável, por meio do decreto n.21.580, de 29 de junho de 1932, no qual ficava explícito que somente o trabalhador que possuísse carteira usufruiriados direitos trabalhistas. $\mathrm{O}$ artigo 26 deixava evidente a relação carteira profissional/trabalhador/direitos: “Após doze meses de vigência do presente decreto, o Ministério do Trabalho, Indústria e Comércio só conhecerá das queixas e reclamações de empregados que possuam carteiras profissionais" (Brasil, 29 jun. 1932). Dessa forma, a carteira demonstrava o "tipo de relação entre cidadão e Estado que se desejava construir" (Gomes, 1988, p.242). Tal relação atingiu seu ápice com a Consolidação das Leis do Trabalho (CLT) promulgada a partir do decreto-lei n.5.452, de $1^{\circ}$ de maio de 1943 (French, 2001).

Antes da emissão da carteira, todos os dados pessoais e profissionais dos trabalhadores eram registrados em um documento chamado ficha de qualificação profissional, ou fichaespelho. O objetivo deste artigo é averiguar as fichas de 62 trabalhadores que, ao solicitarem suas carteiras, tiveram um sinal particular registrado relacionado com uma doença: a varíola. Pretende-se analisar as fotografias em formato 3x4 de alguns desses trabalhadores, além de outros dados registrados em suas solicitações. Trabalhar com as fotografias desses trabalhadores marcados com a varíola é demonstrar como a doença era severa com os contagiados que, se sobrevivessem, teriam de conviver com as marcas. Também se tem como objetivo aqui apresentar um pouco da própria história da doença, já que há poucas informações sobre as epidemias de varíola no Rio Grande do Sul. Outro aspecto importante é abordar a própria história dos trabalhadores. Como será desenvolvido adiante, pouco se sabe a respeito da maioria daqueles que solicitaram carteira profissional, e o acervo da Delegacia Regional do Trabalho do Rio Grande do Sul (DRT-RS) possibilita compreender um pouco a trajetória profissional, especificamente, dos sobreviventes da varíola. As fotografias $3 \times 4$ contribuem para isso e constituem o fio condutor para o desenvolvimento dos objetivos do artigo.

A análise das fotografias 3x4 dos trabalhadores com sinais de varíola ampara-se na proposta metodológica desenvolvida por Ana Maria Mauad, que pondera a fotografia como imagem/ documento: "considera-se a fotografia como índice, como marca de uma materialidade passada, na qual objetos, pessoas, lugares nos informam sobre determinados aspectos desse passado - condições de vida, moda, infraestrutura urbana ou rural, condições de trabalho etc." (Mauad, 2008, p.37).

Ainda no que se refere aos aspectos metodológicos, Ana Maria Mauad (2008, p.40) explica que o corpus fotográfico pode ser organizado em função do tema ou por meio das diferentes agências de produção, entre as quais está o Estado. O conjunto de fotografias 3x4 foi produzido pelo Estado brasileiro, a partir das demandas do Ministério do Trabalho, Indústria e Comércio, e, notadamente, pela Delegacia Regional do Trabalho (DRT).

Neste artigo será estudada uma seleção das fotografias 3x4 organizadas a partir dos sinais particulares dos trabalhadores marcados pela varíola. Essas fotografias não apresentam apenas o rosto dos fotografados, mas os envolvem em um determinado aspecto do passado relacionado com a história do trabalho no Brasil. Como afirma Boris Kossoy (2012, p.41), 
o "ato fotográfico, ou o processo que deu origem a uma representação fotográfica, tem seu desenrolar em um momento histórico específico (caracterizado por um determinado contexto econômico, social, político, religioso, estético etc.)". As fotografias 3x4 dos trabalhadores com sinais de varíola evidenciam, entre tantas outras fotografias conservadas no acervo da DRT-RS, a relação entre a carteira profissional e as políticas trabalhistas no Brasil dos anos 1930.

\section{As fichas de qualificação profissional e a fotografia como controle do Estado}

O preenchimento das fichas de qualificação profissional (Figura 1), no caso do Rio Grande do Sul, era realizado na sede da Inspetoria Regional do Trabalho, em Porto Alegre, diretamente nas fábricas e estabelecimentos comerciais ou, então, pelo identificador, que percorria o estado coletando as informações e registrando-as nas fichas (Loner, 2010). Em 1940, a inspetoria foi transformada em Delegacia Regional do Trabalho e começou a instalar postos de atendimento e de solicitação de carteiras em cidades do interior do estado. O primeiro, em Passo Fundo, foi instalado em 1945, e o segundo, em Pelotas, em 1948 (Loner, 2008).

As fichas de qualificação profissional preenchidas entre 1933 e 1968 foram preservadas e, desde 2001, estão sob os cuidados do Núcleo de Documentação Histórica da Universidade Federal de Pelotas (NDH/UFPel). O acervo é composto por 627 mil fichas com dados de trabalhadores de todas as regiões do estado. ${ }^{1}$
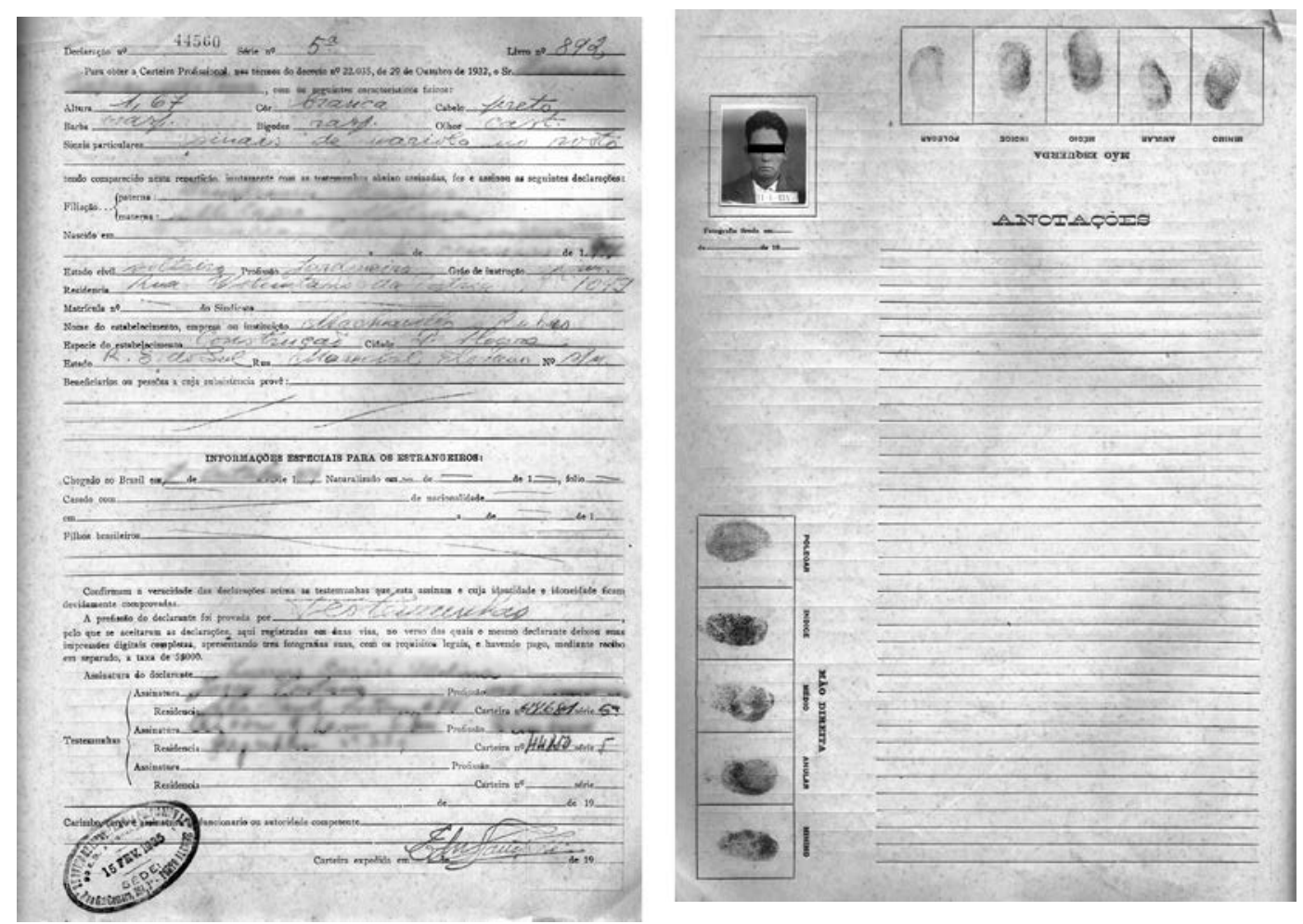

Figura 1: Ficha de qualificação profissional (frente e verso) de trabalhador identificado por sinal particular associado a varíola (Fonte: DRT-RS; acervo: NDH/UFPel) 
O registro dos dados do trabalhador era composto por vários campos que permitiam inserir dados pessoais, como nome, data de nascimento, cidade e país de nascimento, sexo, estado civil, número de dependentes, os quais poderiam ser a esposa, os filhos ou os pais, e residência. A ficha também registrava os dados profissionais: profissão, tipo, nome do estabelecimento. Caso o trabalhador estivesse vinculado a algum sindicato, tal informação também poderia ser registrada na sua ficha e, consequentemente, na sua carteira profissional. De acordo com Angela de Castro Gomes (1988, p.176): "De um lado, existia um sindicalismo atrelado ao Ministério do Trabalho, composto por entidades, em parte reais e em parte fictícias, e, de outro, havia sindicatos que, mesmo tendo reconhecimento oficial, permaneciam sob o controle de lideranças de esquerda". Dessa forma, seria possível identificar, por parte do empregador e do governo, a qual sindicato o trabalhador estava vinculado.

Se o trabalhador fosse estrangeiro, eram solicitadas informações sobre o ano da chegada ao Brasil e o ano da naturalização, se fosse o caso. Outras informações permitem saber o grau de instrução do trabalhador. Informações antropométricas constituíam parte dos dados: altura, cor da pele, cor de cabelo, cor dos olhos e, se fosse homem, barba e bigode. É nesse conjunto que aparecia o campo "sinais particulares". Nele se registravam, por exemplo, marcas de nascimento, falta de dedos ou falanges, problemas oculares ou ausência de olhos, calvície, cicatrizes, sinais de varíola, deficiências físicas, queimaduras, entre outros. Todos esses campos localizavam-se na primeira página da ficha, que continha ainda a data e o número da solicitação da carteira, o número e a série do livro e se era uma segunda via.

No verso da ficha constavam uma fotografia $3 \times 4$ do trabalhador, as impressões dos dedos das mãos e, se fosse preciso, outras informações. Conforme o parágrafo primeiro do artigo segundo do decreto que criou a carteira profissional, a fotografia era parte obrigatória: " 1 . Fotografia com a menção da data em que tiver sido tirada". No mesmo decreto, era prevista a forma como a fotografia deveria ser apresentada: "Art. $6^{\circ}$. As fotografias que figurarão na carteira deverão reproduzir a imagem da cabeça tomada de frente, com as dimensões aproximadas de três centímetros por quatro, tendo, num dos ângulos, em algarismos bem visíveis, a data em que tiverem sido feitas, não se admitindo fotografias tiradas mais de um ano antes da sua apresentação" (Brasil, 29 jun. 1932). O decreto ainda estipulava em outro artigo a obrigatoriedade do fornecimento de três fotografias.

O uso da fotografia, assim como todos os dados registrados, configura uma forma de controle do trabalhador por parte do Estado brasileiro. Além de um controle direto, materializado na criação da carteira profissional, na obrigação da sua solicitação e nos registro nela conferidos ao trabalhador, o Estado conservava em suas dependências oficiais a fotografia do cidadão. A utilização de fotografias como forma de controle do Estado, entretanto, não foi uma novidade do governo brasileiro nos anos 1930. O emprego desse tipo de registro foi verificado logo após o surgimento da fotografia no século XIX. John Tagg (2002, p.62) afirma que, no decurso das transformações políticas e sociais nas sociedades capitalistas avançadas, o exercício do poder foi reestruturado e o controle estatal foi auxiliado por uma nova "tecnologia" difundida em instituições como escolas, hospitais e prisões. Ou seja, o recurso fotográfico passou a ser utilizado como uma forma de controle. Nas palavras do autor: 
As condições para um encontro marcante estavam postas - cujas consequências ainda estamos vivendo - entre uma forma romanceada de Estado e uma tecnologia do conhecimento nova e em desenvolvimento. A chave dessa tecnologia a partir dos anos 1870 estava na fotografia, e é nos trabalhos do complexo expandido de Estado que devemos buscá-la se quisermos entender a força que a fotografia passou a ter no final do século XIX (Tagg, 2002, p.63). ${ }^{2}$

John Tagg (2002, p.64) também aponta que a fotografia forneceu uma técnica central para as reformas sanitárias e a supervisão policial, sendo este o fio condutor que permite analisar as relações entre a fotografia e o Estado. Percepção semelhante foi desenvolvida pelo Estado brasileiro. Além da carteira profissional como forma de controle dos trabalhadores, o governo arquivava as fotografias dos solicitantes. Dos três exemplares fotográficos do rosto do trabalhador exigidos apenas um retornava, fixado na carteira. Os demais ficavam com o governo; um deles constituía parte dos registros na capital federal, diretamente no Ministério do Trabalho, Indústria e Comércio, e o outro fazia parte da ficha de qualificação, arquivada na Inspetoria Regional no estado em que o documento fora solicitado.

A fotografia serviu como tentativa de o Estado controlar os cidadãos. Parte dessa utilização foi direcionada àqueles que corrompiam as normas vigentes, e essa apropriação surgiu logo após a criação da nova técnica. Para Annateresa Fabris (2004, p.40):

A sociedade do século XIX, ao conferir à imagem fotográfica o papel de atestado de uma existência, faz do retrato um instrumento de recenseamento generalizado, que tanto pode exaltar os feitos do indivíduo, quanto pode apontar à atenção pública aqueles que apresentam desvios patológicos.

A autora se refere, sobretudo, ao uso da fotografia nas esferas médica e jurídica. Nesse sentido, um dos mais relevantes empregos da fotografia foi desenvolvido por Alphonse Bertillon, chefe do Serviço de Identidade Judiciária da Polícia de Paris (Dubois, 1993, p.241). O sistema de Bertillon, chamado de identificação antropométrica, consistia em instituir uma identidade individual de maneira infalível:

Trata-se da fotografia (o doravante absoluto face/perfil, muito rigorosamente fotografado), da mensuração antropométrica (a medida em números de cada parte fixa do corpo: nariz, olhos, queixo, dedos, pés, orelhas etc.) e da sinalética do 'retrato falado' (a descrição verbal dos elementos fisionômicos e das marcas corporais de todos os tipos) (Dubois, 1993, p.241; destaque no original).

Philippe Dubois ainda informa que tais dados foram complementados, em 1902, com o acréscimo da impressão digital na ficha policial. Inspirado por Bertillon e por outros criminologistas europeus, o médico porto-alegrense Sebastião Leão realizou estudos com os prisioneiros da Casa de Correção em Porto Alegre no final do século XIX. O médico transformou a cadeia em "seu campo de investigações científicas. Tinha à mão uma populaçãoalvo para experimentação dos diferentes métodos classificatórios em voga" (Pesavento, 2009 , p.52). O resultado de suas investigações foi publicado em um relatório acompanhado de um álbum fotográfico em 1897. Nele, o médico apresentou fotografias de face e de perfil e descrições antropométricas dos prisioneiros (p.123-377). Nota-se a semelhança entre os exemplos citados e a ficha de qualificação profissional criada pelo governo brasileiro nos anos 
1930, ou seja, além da fotografia, os dados antropométricos também constam das informações que deveriam ser declaradas pelo trabalhador. É provável que o modelo da ficha tenha se inspirado em outros já existentes, visando o controle dos trabalhadores.

Já a fotografia no formato $3 \times 4$ dos trabalhadores brasileiros tem uma relação mais próxima com aquela realizada por Bertillon: "A execução do famoso retrato duplo, de frente e de perfil, é assim definida em seus mínimos detalhes: 'Para a pose de frente, focar o ângulo externo do olho esquerdo; para a de perfil, o ângulo externo do olho direito'” (Rouillé, 2009, p.87). As imagens dos trabalhadores - exemplificadas por aquelas dos marcados pela varíola - foram realizadas apenas com a pose de frente, capturada pelo fotógrafo de forma semelhante à fotografia realizada pelo criminologista francês.

A reflexão de André Rouillé é importante para entender a relação entre a fotografia do serviço de identificação da polícia francesa e o que era solicitado pelo Estado brasileiro em relação à confecção da carteira profissional, ao enfatizar que o registro nesse pequeno formato será "significativamente utilizado para documentos de identidades" (Rouillé, 2009, p.88). Para o autor, "enquanto a forma 'artística e comercial' do retrato de ateliê acredita exprimir a individualidade do modelo, a do clichê de polícia só procura registrar a identidade do detento" (p.88). As fotografias 3x4 produzidas no Brasil, apesar de seu objetivo final ser outro, igualmente registram a identidade do trabalhador e, no conjunto dos registros analisados neste texto, revelam os sinais particulares deixados pela varíola em seus rostos.

\section{Os sinais da varíola e as fotografias dos trabalhadores}

Um dos principais propagandistas do ideário republicano no Rio Grande do Sul foi Júlio de Castilhos, que desenvolveu sua proposta republicana e positivista nas páginas do periódico A Federação. Em 1891, Castilhos assumia o poder no estado, e dois anos depois enfrentava a Revolução Federalista (1893-1895), combatendo aqueles que constituíam um grupo opositor a sua administração autoritária. O positivista enérgico, advogado por formação e político e jornalista por vocação, contraiu uma doença que deixou marcas gravadas para sempre em sua pele: "Foi ainda à altura de seus 14 anos que Júlio contraiu varíola, quase encontrando a morte. Dura provação essa, de que conservaria o estigma para o resto da existência, na face marcada de bexigas" (Franco, 1996, p.14).

Também no universo literário, determinadas obras fazem referências à varíola. A doença foi empregada na ficção como uma forma de castigar mulheres bonitas. Machado de Assis, em Memórias póstumas de Brás Cubas, descreve a personagem Marcela como uma sobrevivente da doença, mas com suas sequelas características: "As bexigas tinham sido terríveis; os sinais, grandes e muitos, faziam saliências e escarnas, declives e aclives, e davam uma sensação de lixa grossa, enormemente grossa" (Assis, 2004, p.77). Ainda na literatura do século XIX, Émile Zola mata a protagonista de seu livro Naná com a doença:

Aquilo era um horror, um montão de humores e sangue, uma porção de carne corrompida, deitada ali sobre o travesseiro. As pústulas tinham invadido todo o rosto, as bexigas ligadas umas às outras; e fanadas, apagadas, com um aspecto pardacento de lama, pareciam já um montão de terra, sobre aquela cara informe, onde não se distinguiam já feições (Zola, 1982, p.380). ${ }^{3}$ 
Contudo, por que a doença marcou para sempre a vida de Júlio de Castilhos e foi usada para condenar personagens literários? A resposta está nos efeitos causados no doente que sobreviveu. Os adjetivos "bexiga" ou "bexiguento", denominações populares usadas para identificar os sobreviventes da varíola, referiam-se aos sinais que ficavam nas áreas da pele do doente infectado, os quais se assemelhavam a bexigas. No caso dos surtos ocorridos no Brasil, é possível identificar o uso do termo, por exemplo, em documentos do século XVII que tratam de uma epidemia ocorrida em 1661 no Maranhão (Chambouleyron et al., 2011, p.998). ${ }^{4}$

A varíola, portanto, é uma doença viral, sistêmica e aguda, e suas epidemias causavam grande número de vítimas; as que sobreviviam precisavam conviver com suas marcas. Segundo Carlos Machado (1989, p.875), a doença é "conhecida desde a mais remota Antiguidade, admite-se que os primeiros casos de varíola se verificaram no nordeste da África, na China e na Índia, muito antes da Era Cristã. Depois disso, nenhum continente ficou livre da varíola".

Ainda segundo o autor, cerca de três dias após o aparecimento de sintomas - como febre, dor de cabeça e náuseas - surgem pequenas manchas vermelho-rosadas pelo rosto que se alastram depois por quase todo o corpo (erupção cutânea). Se o paciente sobrevivesse, as pústulas secavam após 12 dias e formavam cicatrizes. Conforme aponta Paulo Quaresma (2012, p.46): "O contágio acontecia, de regra, através do estreito contato com as secreções das vias respiratórias e das lesões da pele de pacientes, ou com os objetos recém-contaminados". A fácil propagação da doença demonstra o medo ocasionado pelos surtos.

Antes da erradicação da varíola nos anos $1970,{ }^{5}$ o Brasil e o mundo sofreram vários surtos epidêmicos, os quais deixaram "um rastro de mortes, cegueira e cicatrizes irreversíveis" (Schatzmayr, 2001, p.1526). Muitos homens e mulheres foram contaminados, mas sobreviveram, com as suas marcas e estigmas, entre os quais estavam trabalhadores e trabalhadoras que solicitaram suas carteiras profissionais, no Rio Grande do Sul, a partir dos anos 1930.

A identificação dos 62 trabalhadores que tiveram varíola e solicitaram carteira de trabalho dá-se a partir da verificação do campo "sinais particulares" da ficha de qualificação profissional. A pesquisa mostrou que não eram descritos somente como "sinais de varíola", mas de forma variada (Tabelas 1 e 2).

Nas Tabelas 1 e 2 verifica-se que houve uma predominância em descrever o sinal particular do trabalhador como "varíola" ou "varicela" (36 trabalhadores), enquanto a descriçao como "bexiga" foi menor (26 trabalhadores). No entanto, é possível verificar que as formas como os sinais ocasionados pela doença foram registrados mudava de trabalhador para trabalhador. Enquanto na maioria das identificações que registram varíola constam "sinais de varíola no rosto" (13 trabalhadores), as demais empregam adjetivos diferenciados, como demonstram os registros transcritos nas tabelas.

Outra parcela de trabalhadores teve a sua particularidade descrita como "pele bichigosa". É possível considerar que tal denominação estava mais associada a uma forma pejorativa do que a uma simples anotação que se refere a um ex-doente de varíola. Essa hipótese, por um lado, leva em consideração que os sinais poderiam ser anotados pelo funcionário da DRT-RS destinado ao preenchimento das fichas sem, necessariamente, perguntar ao trabalhador. Por outro lado, os próprios trabalhadores poderiam assim declarar, e, nesse caso, essa forma de identificação da doença seria algo previamente introjetado. 
Tabela 1: Trabalhador por sinal particular "varíola" ou "varicela"

\begin{tabular}{l|c}
\hline Sinal particular & Número de trabalhadores \\
\hline sinais de varíola no rosto & 13 \\
\hline sinais de varíola & 7 \\
\hline de varíola & 2 \\
\hline cicatriz de varíola & 2 \\
\hline sinal de varíola & 2 \\
\hline sinais no rosto de varíola & 2 \\
\hline sinais de varíola na face & 1 \\
\hline marcas de varíola no rosto & 1 \\
\hline sinais de varicela & 1 \\
\hline sinais de varíola nas faces & 1 \\
\hline alguns sinais de varíola no rosto & 1 \\
\hline cicatrizes de varíola sobre o rosto & 1 \\
\hline sinais de varicela no rosto & 1 \\
\hline cicatrizes de varíola & 1 \\
\hline TOTAL & 36 \\
\hline
\end{tabular}

Fonte: DRT-RS (Acervo: NDH/UFPel).

Tabela 2: Trabalhador por sinal particular "bexiga" ou "pele bichigosa"

\begin{tabular}{l|c}
\hline Sinal particular & Número de trabalhadores \\
\hline sinais de bexiga & 6 \\
\hline pele bichigosa & 5 \\
\hline de bexiga & 2 \\
\hline sinais de bexiga no rosto & 1 \\
\hline tem sinais de bexiga na testa & 1 \\
\hline de bexiga no rosto & 1 \\
\hline sinais acentuados de bexiga no rosto & 1 \\
\hline cicatrizes visíveis de bexiga & 1 \\
\hline poucos sinais de bexiga sobre os lados do nariz & 1 \\
\hline tem sinais de bexigas & 1 \\
\hline rosto picado de bexiga & 1 \\
\hline cicatrizes de bexiga no rosto & 1 \\
\hline tem o rosto com cicatrizes de bexiga & 26 \\
\hline TOTAL & \\
\hline
\end{tabular}

Fonte: DRT-RS (Acervo: NDH/UFPel).

Outra perspectiva de análise, constatada a partir dos dados das fichas e que estão transcritos nas tabelas, refere-se às informações que especificavam a varíola. Dois trabalhadores apresentavam, respectivamente, "alguns sinais de varíola no rosto" e "poucos sinais de bexiga sobre os lados do nariz" (Figura 2), outros quatro possuíam "cicatrizes", um tinha "sinais acentuados", e, outro, "cicatrizes visíveis" (Figura 3). As diferenças na descrição dos sinais da doença demonstram que a varíola poderia deixar a pele com marcas pouco visíveis (Figuras 4 e 5) ou mais severas (Figuras 6 e 7). Dessa forma, foi averiguado que nem sempre a classificação do sinal como "bexiga" ou "pele bichigosa" (Figura 8) significava que a pele do trabalhador era mais marcada pela doença. 
Figura 2:

Trabalhadores

com sinais

particulares,

da esquerda

para a direita:

"Alguns sinais

de varíola

no rosto"

e "Poucos

sinais de

bexiga sobre

os lados do

nariz" (Fonte:

DRT-RS;

acervo: NDH/

UFPel)

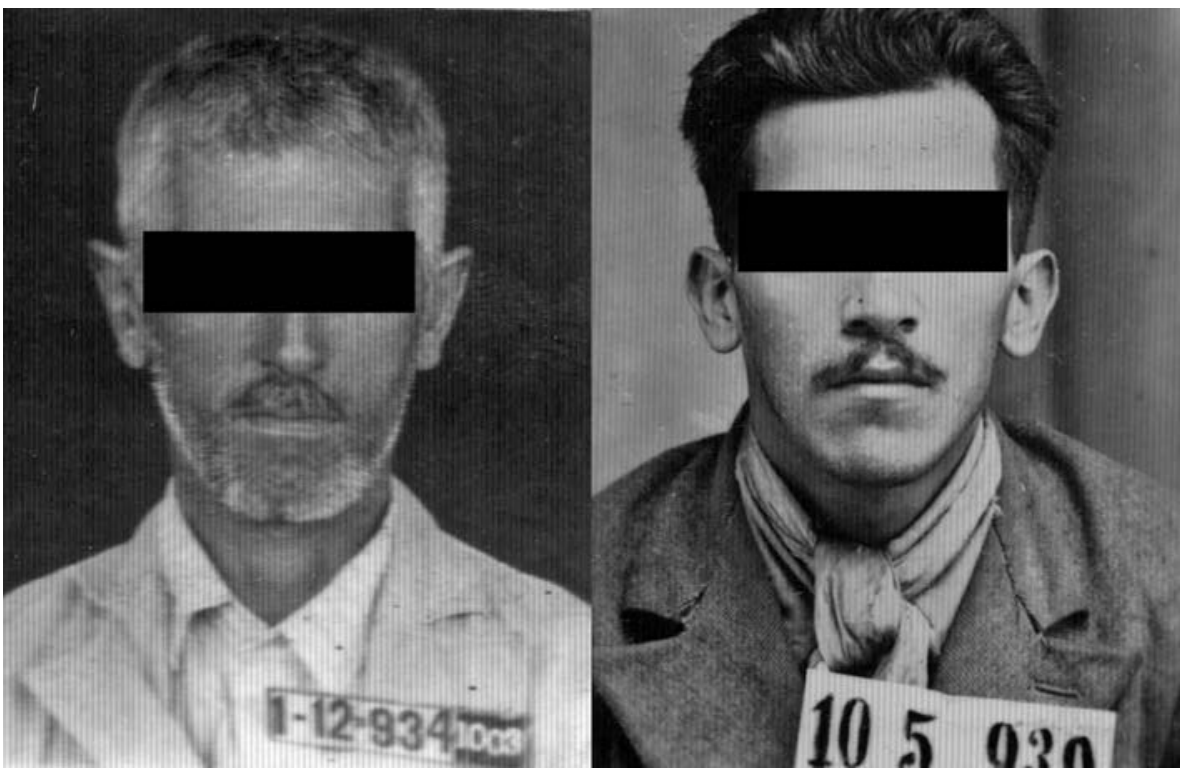

Figura 3:

Trabalhadores identificados

pelos

seguintes

sinais

particulares,

em sentido

horário

iniciando no

canto superior

esquerdo:

"Sinais

acentuados

de bexiga

no rosto",

"Cicatrizes

visíveis de

bexiga",

"Cicatrizes

de bexiga no

rosto" e"Tem

o rosto com

cicatrizes de

bexiga" (Fonte:

DRT-RS; acervo:

NDH/UFPel)
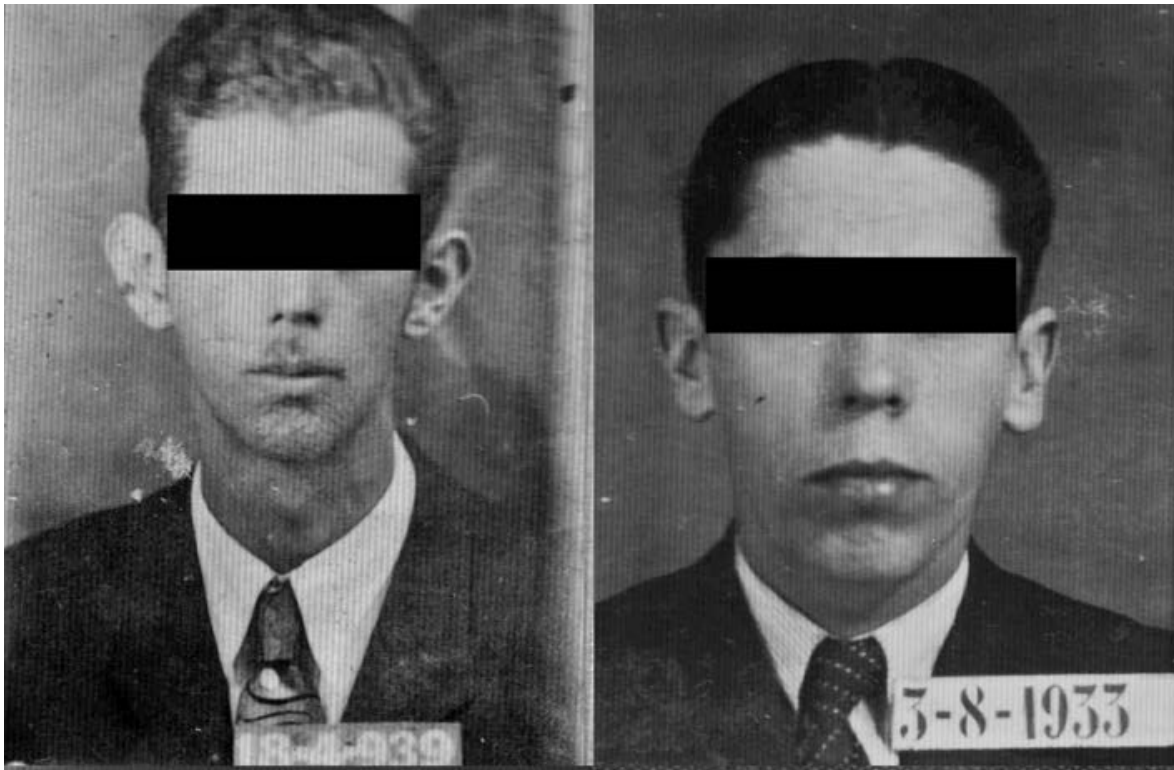

\section{$8 / 694$}
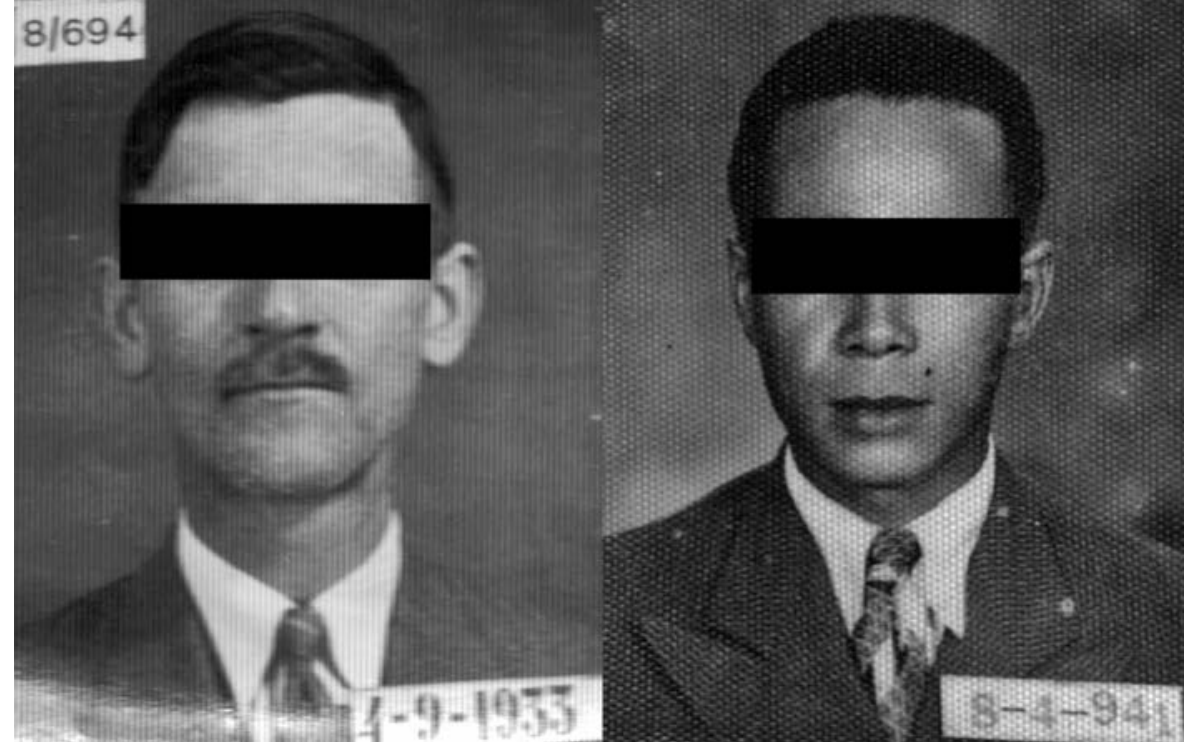


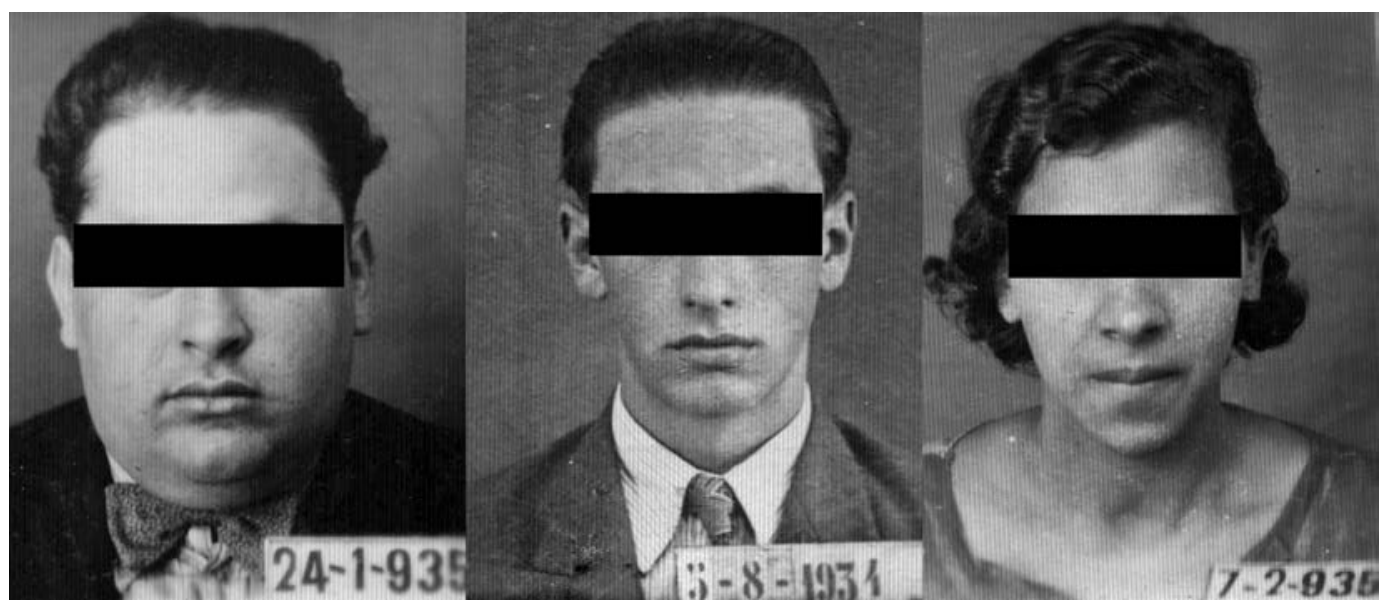

Figura 4: Trabalhadores com sinais particulares, da esquerda para a direita: "Sinais de varíola", "Sinais de varíola" e "Sinais de varíola no rosto" (Fonte: DRT-RS; acervo: NDH/UFPel)

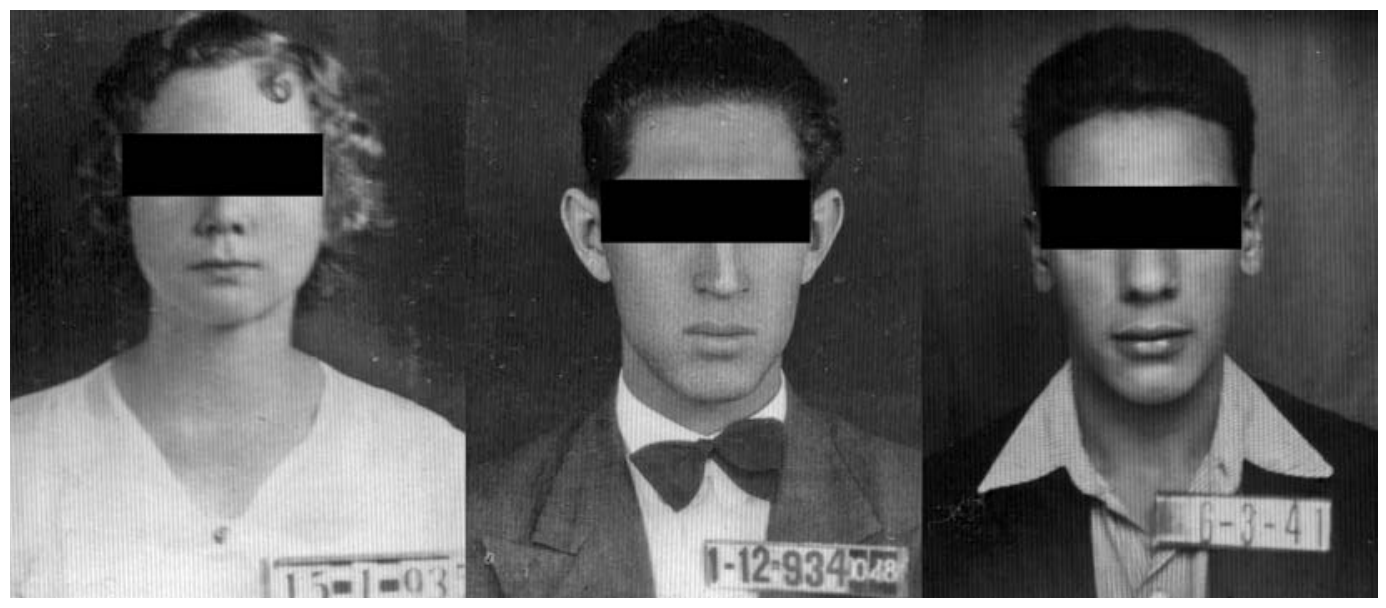

Figura 5: Trabalhadores com sinais particulares, da esquerda para a direita: "Sinais de varíola nas faces", "Sinais de varíola no rosto" e"Tem sinais de bexiga na testa" (Fonte: DRT-RS; acervo: NDH/UFPel)

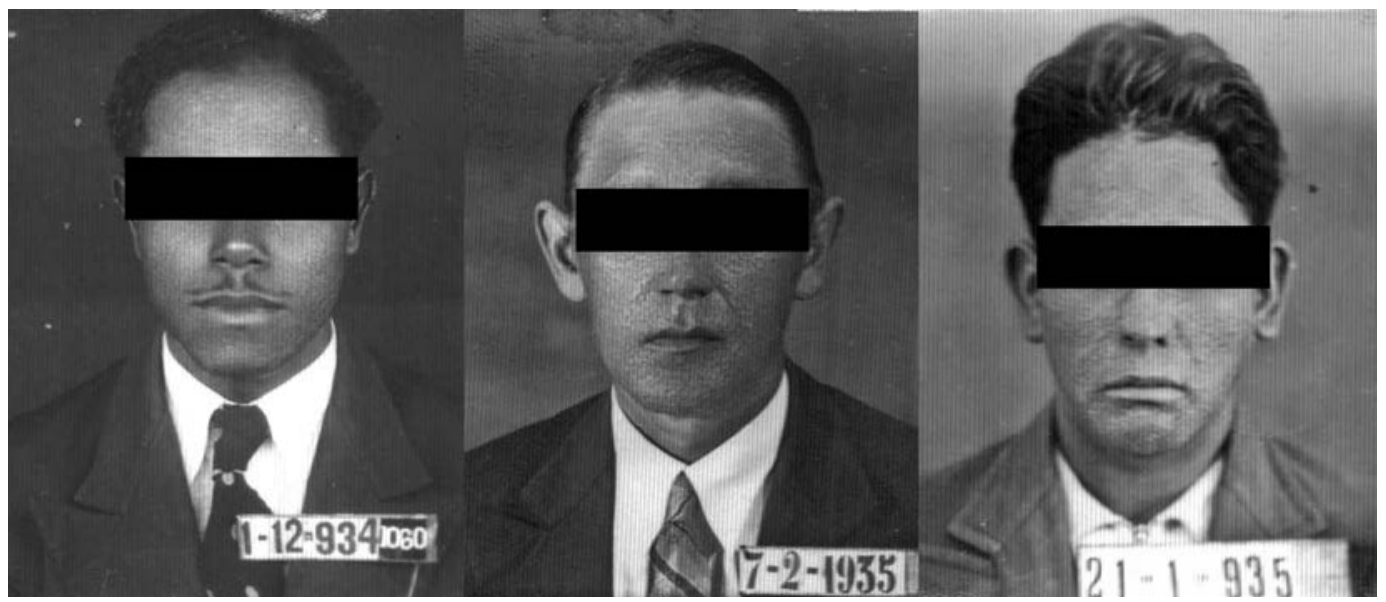

Figura 6: Trabalhadores com sinais particulares, da esquerda para a direita: "Sinais de varíola no rosto", "Sinais de varíola nas faces" e "Sinais de varíola no rosto" (Fonte: DRT-RS; acervo: NDH/UFPel) 


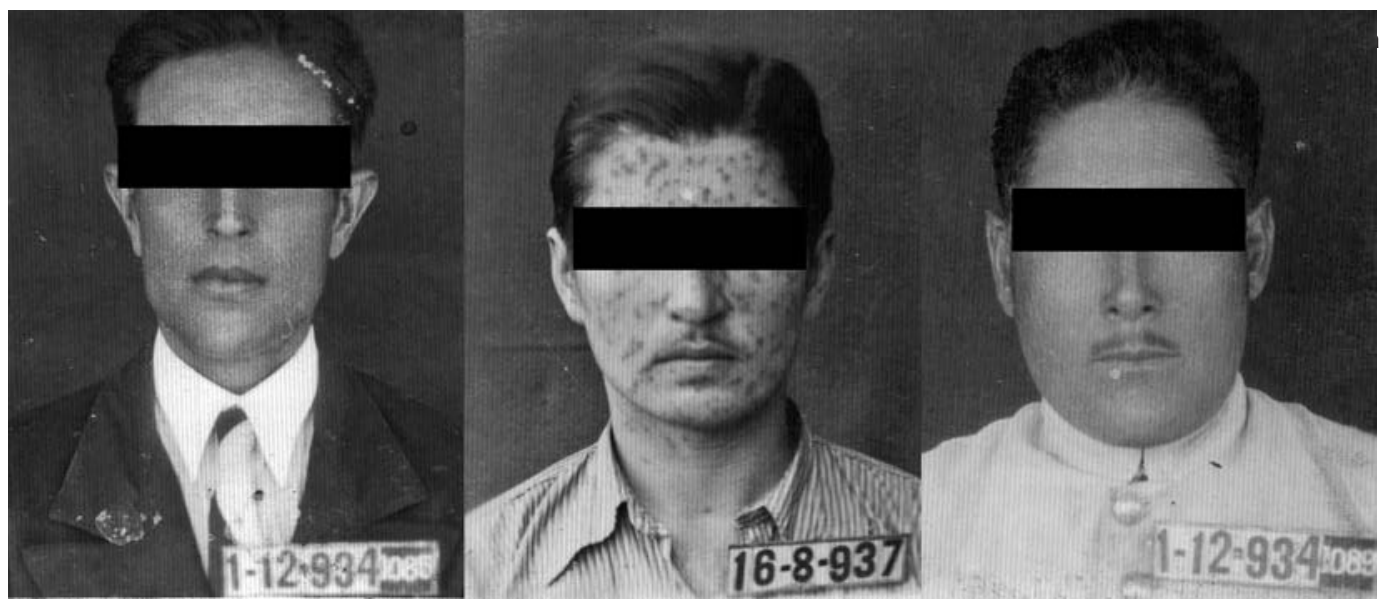

Figura 7: Trabalhadores com sinais particulares, da esquerda para a direita: "Sinais de varíola no rosto", "Sinais de varíola no rosto" e "Sinais de varíola no rosto" (Fonte: DRT-RS; acervo: NDH/UFPel)

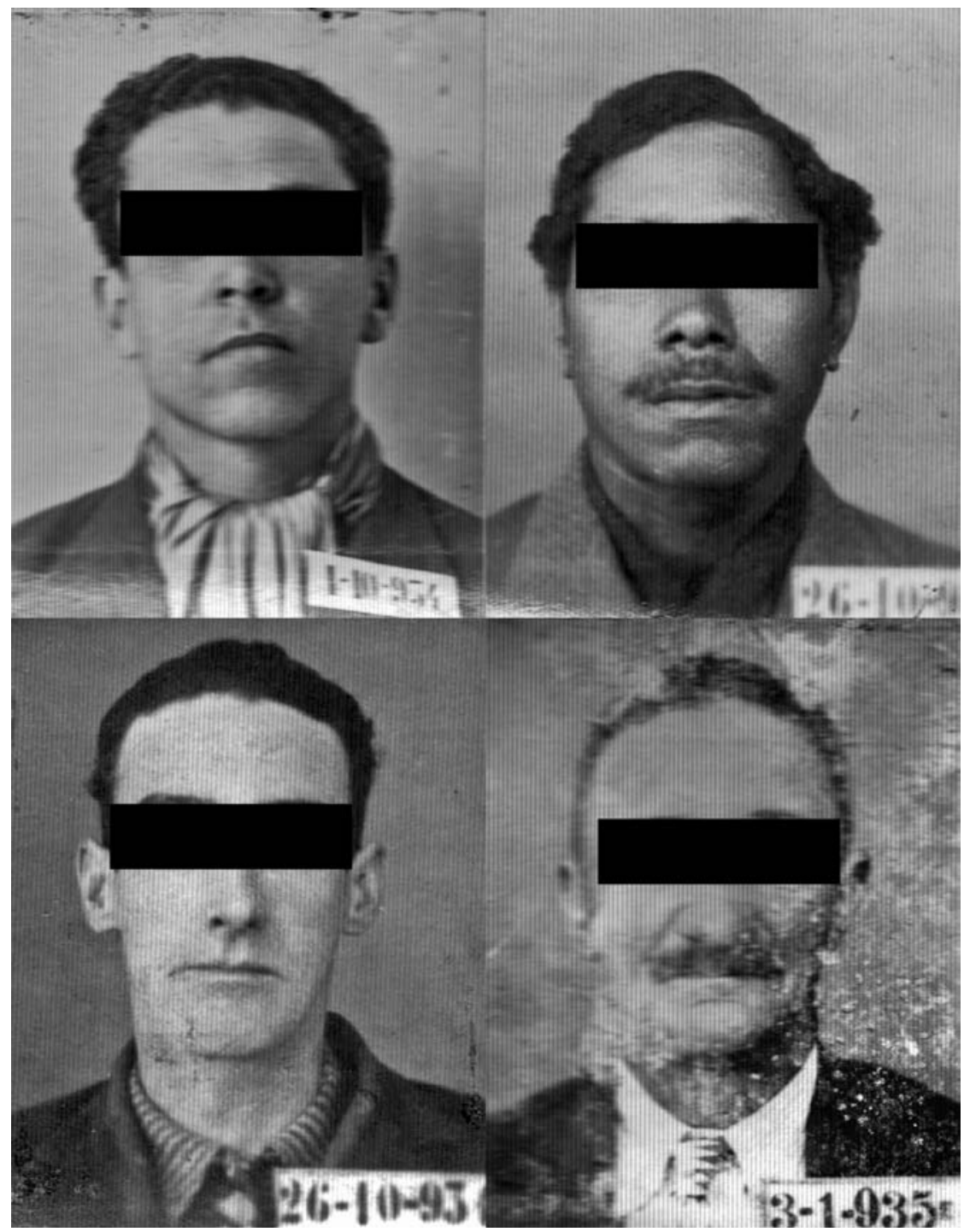

Figura 8: Trabalhadores identificados com o sinal particular "Pele bichigosa" (Fonte: DRT-RS; acervo: NDH/UFPel) 
Alguns indivíduos possuíam sinais mais leves do que outros, e algumas marcas eram ainda mais suaves se comparadas com as de determinados trabalhadores em cuja documentação constava "varíola". Os sinais dos trabalhadores da Figura 3 foram descritos como "bexiga", e as marcas em suas faces, registradas nas fotografias, revelavam-se mais suaves do que aquelas dos trabalhadores das Figuras 6 e 7, descritas como "varíola". Já os trabalhadores das Figuras 4 e 5, cujos sinais também foram descritos com o termo "varíola", são mais suaves do que aqueles dos trabalhadores das Figuras 6 e 7. O sinal do último trabalhador da Figura 5 foi descrito como "bexiga" e localizado na testa. As fotografias dos trabalhadores das Figuras 6 e 7 evidenciavam as marcas severas deixadas pela doença, embora a descrição tenha sido feita pelo termo "varíola". No caso do segundo trabalhador da Figura 7, a fotografia revelava um tipo de cicatrização diferente: a doença deixou marcas que lembravam as pústulas provocadas em uma de suas fases, diferente das marcas dos demais, que apresentavam outro tipo de cicatrização.

Os trabalhadores da Figura 8, descritos como tendo "pele bichigosa", não apresentavam - ao menos não se revela na fotografia de suas faces, com exceção do primeiro trabalhador sinais muito nítidos. Comparando as fotografias desses trabalhadores com as das Figuras 6 e 7, é possível apontar que os rostos nestas últimas figuras tinham marcas mais significativas. O primeiro e o terceiro indivíduos da Figura 5 possuíam marcas mais suaves. Somente pela fotografia, fica difícil verificar a presença de sinais na trabalhadora dessa figura, por exemplo, mas o registro no campo "sinal particular" traz "sinais de varíola nas faces".

Averiguando os dados desses trabalhadores, verifica-se que os sinais particulares possuíam relação com a pele do trabalhador, marcada pela doença e quase sempre exposta na sua fotografia 3x4. Algumas das fotografias não revelam os sinais da varíola, outras apresentam marcas suaves e algumas mostram, com nitidez, os resultados deixados pela doença. É importante destacar que a varíola não deixava marcas apenas no rosto dos vitimados, mas espalhavam-se por todo o corpo. Dessa forma, é possível que alguns trabalhadores tivessem as cicatrizes em outras partes do corpo, o que também levava ao registro de sinais particulares, mesmo que as marcas fossem pouco visíveis ou inexistentes na face do solicitante da carteira. É provável que essa fosse a situação dos trabalhadores registrados com o sinal particular "pele bichigosa".

O número de trabalhadores com sinais da doença ainda é pequeno, e, como apontado anteriormente, é possível que outros sejam encontrados no acervo à medida que a pesquisa avance. Em relação às fotografias, algumas descolaram das fichas e foram perdidas. Até o momento, do grupo de fichas contendo "varíola" ou "varicela" (Tabela 1), foram conservadas trinta fotografias. Entre as seis restantes, três ainda permanecem nas fichas, mas apagadas pelo tempo. No outro grupo, de fichas com os termos "bexiga" ou "pele bichigosa" (Tabela 2), foram preservadas 22 fotografias.

Importante destacar que as fichas da DRT-RS registraram os trabalhadores com sinais de varíola sem que tal particularidade fosse relevante para a solicitação da carteira. O campo "sinais particulares" era utilizado para identificar determinadas características visíveis do trabalhador; entre as possíveis, estavam marcas decorrentes de varíola. Contudo, tais fotografias se somam a outras, usadas em outros momentos e com objetivos diferentes, que registraram 
pessoas e suas enfermidades. Para James Silva, a fotografia utilizada pela ciência significou uma renovação das expectativas:

Com ela, acreditou-se que se poderia ir muito mais além na investigação científica, o que serviu de móvel para sensibilizar o estado para o apoio a novas experimentações, a projetos de aperfeiçoamento técnico e de expedições científicas envolvendo a fotografia como recurso investigativo e documental (Silva, 2003, p.73).

A partir das últimas décadas do século XIX, surgiram estudos e álbuns fotográficos de instituições médicas registrando seus doentes e os males que os afligiam. Em 1868, o Hospital Saint-Louis abriu um estúdio de fotografias que originou duas publicações: Clinique Photographique de l'Hôpital Saint-Louis e Revue Photographique des Hôpitaux de Paris (Rouillé, 2009, p.114). Antes do lançamento dessas obras, e também na França, outro hospital, o Salpêtrière, registrou doentes epiléticos e histéricos. O primeiro tomo da obra Iconographie photographique de la Salpêtrière foi publicado em 1858 (Rouillé, 2009, p.115). O médico e cientista Jean-Martin Charcot foi um dos responsáveis pelos registros fotográficos dos pacientes do Salpêtrière, os quais continuaram nos anos seguintes. Em 1888, por exemplo, foi publicado Nouvelle iconographie de la Salpêtrière, ainda sob os cuidados de Charcot e com a colaboração dos médicos Gilles de la Tourette e Paul Richer (Didi-Huberman, 2003, p.45).

Em 1876, Guillaume Duchenne de Boulogne, com a colaboração do fotógrafo Adrien Tournachon, realizou as séries fotográficas com expressões faciais dos pacientes sob estímulo de correntes elétricas, dando origem ao álbum Mécanisme de la physionomie humaine: études des mouvements musculaires par contraction électrique (Silva, 2003, p.77). A fotografia transformavase em um importante método de registro e estudo, colaborando com as pesquisas médicas. Uma das áreas que valorizaram a fotografia foi a psiquiatria, que "buscava sua legitimação através da fotografia, retomando uma antiga tradição de representação fisionômica da doença mental" (Hochman, Mello, Santos, 2002, p.239).

A fotografia como investigação científica relacionada à área da saúde foi empregada no Brasil em expedições realizadas por médicos e pesquisadores do Instituto Oswaldo Cruz, entre 1911 e 1913, das quais resultaram "imagens que reproduzem, em plano fechado ou em detalhe, aspectos da fauna, da flora e de doentes com sintomas visíveis das doenças encontradas nas regiões percorridas" (Mello, Pires-Alves, 2009, p.154). Registros fotográficos sobre tecnologias e técnicas de combate à malária, bem como de pacientes em tratamento, foram realizados nas primeiras décadas do século XX (Hochman, Mello, Santos, 2002; Lacerda, 2002). Já o médico Heráclides César de Souza-Araújo publicou em três volumes a História da lepra no Brasil, entre 1946 e 1956, sendo o segundo tomo composto por imagens de pacientes (Schneider, 2011).

Esses são apenas alguns exemplos do uso da fotografia associado ao campo da medicina. Eles identificam como a prática do recurso fotográfico foi difundida para registrar as doenças e os doentes num momento logo posterior ao surgimento da fotografia. Annateresa Fabris (2004, p.49), ao comentar as fotografias relacionadas à psiquiatria, pondera que "o retrato fotográfico, finalmente, proporcionava um registro perfeito e fiel, longe de toda caricatura e das imprecisões da descrição verbal". 
As fotografias $3 \times 4$ analisadas neste texto registraram os sinais da varíola visíveis nos rostos daqueles trabalhadores. Embora não fosse o motivo pelo qual esses homens e mulheres foram fotografados, seus registros contribuem para o estudo das relações entre a fotografia e as doenças. Outra importante justificativa para o exercício de análise desenvolvido neste texto é o fato de que todas as fotografias apresentadas são de trabalhadores comuns, ou seja, nenhum deles foi, por exemplo, uma liderança sindical, o que poderia destacá-los dos demais, permitindo, entre outras possibilidades, a confecção de uma biografia. ${ }^{6}$ Esses homens e mulheres não possuíam, até então, referências no passado - alguns, talvez, nem mesmo se conservaram nas memórias familiares, uma vez que vários nasceram no século XIX e acabaram esquecidos por seus descendentes.

A referência ao passado desses trabalhadores comuns é possível somente a partir dos dados da sua ficha de qualificação profissional, conservada pelo acervo da DRT-RS, e, para alguns deles, também de sua fotografia $3 \times 4$. Se considerarmos que a fotografia tornou-se mais habitual para uma parcela da população mundial a partir de meados do século XIX, a outra parcela nem sempre teve acesso a registros fotográficos ou recursos para realizá-los. O carte de visite, comum entre as elites, transformou-se em uma lembrança do fotografado, que oferecia a sua imagem. Annateresa Fabris (2008, p.20) explica que o "cartão de visita supre a 'ausência do retrato' nas classes menos favorecidas, mas à sua difusão capilar a alta burguesia opõe uma série de estratégias de diferenciação, negadoras da multiplicidade". Ainda segundo a autora, a elite buscava outras formas de registros, mais caras, como o daguerreótipo e a fotografia pintada, privilegiando os artistas fotógrafos: "Os altos preços do daguerreótipo e das produções de fotógrafos como Nadar, Carjat, Le Gray colocam o retrato num âmbito social restrito, permitindo-lhe atestar apenas a ascensão da alta burguesia" (p.29). O alcance do registro fotográfico começou a se transformar na década de 1850, justamente com a invenção do carte de visite, por André Adolphe Eugène Disderi, que continuava sendo acessível em grande parte à burguesia, mas agora também aos mais pobres, difundindo-se entre as classes trabalhadoras.

O formato da fotografia poderia focalizar o corpo inteiro, o busto ou o rosto do fotografado. Os registros do rosto acabaram gerando certa padronização dos fotografados, ou seja, se no retrato burguês havia "um certo tipo de pose, um fundo determinado, uma iluminação particular" (Fabris, 2009, p.45), na fotografia em pequeno formato os adereços quase sempre são desnecessários para compor o fundo e o cenário. Outra característica que ajudou o cartão de visita a se difundir foi que ele "podia ser adquirido a partir de quatro unidades, e quantas mais se quisessem, e ser oferecido a quem desejasse, geralmente com dedicatórias no verso" (Koutsoukos, 2010, p.35). Décadas mais tarde, em 1926, surgiu o photomaton, o retrato automático (Rouillé, 2009, p.88), e é esse o modelo, associado àquele de Disderi, que vai possibilitar o surgimento das pequenas fotografias, como as que são apresentadas neste texto.

Muitos cartes de visite e fotografias se preservaram, constituem acervos fotográficos importantes ou estão sob os cuidados de familiares. Enquanto isso, uma parcela significativa da população não teve sua imagem preservada. É justamente nesse contexto que as fotografias do acervo da DRT-RS se incluem, ou seja, não se trata de um carte de visite ou de um photomaton, mas de uma fotografia $3 \times 4$, não é uma lembrança oferecida, mas uma fotografia para um documento oficial; contudo, essa pequena fotografia talvez seja a única imagem preservada 
desse trabalhador. A preservação ocorreu, primeiro, pela conservação como um todo do próprio acervo da DRT-RS. Segundo, porque a fotografia era uma exigência para a confecção da carteira profissional. Como mencionado anteriormente, o formato $3 \times 4$ era exigido no decreto que criou a carteira e também servia para que o Estado controlasse os trabalhadores. Ana Mauad (2008, p.31) esclarece: "No plano do controle social, a imagem fotográfica foi associada à identificação, passando a figurar, desde o início do século XX, em identidades, passaportes e nos mais diferentes tipos de carteiras de reconhecimento social".

Dessa forma, as fotografias deveriam apresentar o rosto do trabalhador no formato que ficou conhecido como 3x4. Essas fotografias identificavam o trabalhador e, ao mesmo tempo, apresentavam o seu semblante: a cor da sua pele, a forma dos seus cabelos, os bigodes e as barbas dos homens. Igualmente, apresentavam os objetos usados para o registro: lenços, gravatas, camisas, casacos usados pelos homens e joias (brincos, correntes, colares), vestidos, casacos, blusas usadas pelas mulheres. O registro fotográfico também identificava os sinais particulares, entre outros, aqueles deixados pela varíola.

A partir das fotografias dos trabalhadores com sinais de varíola, é possível ponderar que seus registros revelam algo próximo do que é apontado por Annateresa Fabris (2004, p.58) como uma identidade retórica ou ficcional. Para a autora, o retrato fotográfico oitocentista apresenta uma construção, já que a pose não é apenas estética, mas também é a "própria concepção de identidade". Assim, é graças à pose que "o sujeito torna-se um modelo; deixa-se captar como uma forma entre outras, ao interagir com o cenário que lhe confere uma identidade retórica quando não fictícia, fruto de uma composição plástica e social a um só tempo" (p.58). As fotografias 3x4 dos trabalhadores não apresentam cenários, mas eles também se tornam modelos, seus adereços lhes conferem uma identidade que poderia estar dissociada da sua condição de trabalho, por exemplo.

Os homens da Figura 3, assim como a maioria dos outros trabalhadores das demais imagens, deixaram-se registrar com terno e gravata ou gravata-borboleta - vestir-se com tais trajes poderia ser algo corriqueiro no Brasil dos anos 1930 e 1940, mas o desempenho de suas profissões nem sempre requeria que eles usassem tais vestimentas. Os trabalhadores da Figura 3 declararam como profissão, respectivamente: mecânico; empregado em uma drogaria; alfaiate; e farmacêutico. O primeiro da Figura 4 trabalhava em um centro esportivo, e o segundo era pedreiro. O primeiro trabalhador da Figura 7 era ferroviário, e o último da Figura 8 era estivador.

É possível que apenas as profissões relacionadas ao comércio e o alfaiate necessitassem vestir tais trajes para exercer seus ofícios. Esses registros fotográficos contribuem, assim, para a construção de uma identidade retórica - semelhante ao que foi apontado por Annateresa Fabris -, ou seja, nem sempre representam a condição de vida do trabalhador. Contudo, as fotografias 3x4 revelam uma unicidade em sua produção: os fotografados estão sempre com uma expressão séria, rígidos, encarando o fotógrafo, geralmente estão vestindo sua melhor roupa, os homens com as gravatas alinhadas, os bigodes aparados e os cabelos sempre bem penteados. Se, por um lado, essas características permitem tomar as fotografias 3x4 como semelhantes, por outro, os fotografados ensejam identidades distintas, retóricas.

Dentre os 62 trabalhadores identificados com sinais particulares, apenas nove são mulheres. Esse dado, contudo, não permite inferir que mais homens tivessem contraído varíola do que 
mulheres. Essa informação está de acordo com o universo dos trabalhadores do estado do Rio Grande do Sul, que, entre as décadas de 1930 e 1940, era ocupado, sobretudo, pela mão de obra masculina (FEE, 1981, p.144). Do total de trabalhadores que requisitaram a carteira profissional, os homens representam, até o momento da digitação dos dados no banco, 78\% dos pedidos.

Já no que se refere ao local de nascimento, a maioria declara ser do Rio Grande do Sul. Porto Alegre se destaca com 13 trabalhadores, outros nasceram nas cidades de Viamão, Gravataí, São Leopoldo, Bagé, Pinheiro Machado, Camaquã, Dom Pedrito, Uruguaiana, Itaqui, Passo Fundo, Lajeado, Taquara, Rio Grande e Pelotas. Outros dois nasceram na cidade de Tubarão, em Santa Catarina. Havia também trabalhadores nascidos no exterior: Montevidéu (Uruguai), Riga (Rússia), Cáli (Colômbia), e Cortegaço, Porto e Lisboa (Portugal). Muitos desses residiam, no momento em que solicitaram a carteira, em cidades diferentes daquelas em que nasceram. Nesse caso, a predominância novamente é Porto Alegre, com 22 trabalhadores.

Não é possível, somente a partir dos dados das fichas, saber o ano em que o trabalhador enfrentou a varíola. Entretanto, os variados locais de nascimento e de residência dos trabalhadores indicam que a doença não estava restrita somente a uma região ou a um país. No caso do Rio Grande do Sul, havia trabalhadores nascidos em cidades geograficamente distantes, como exemplificam a capital Porto Alegre e sua atual região metropolitana, em relação ao sul, com Pelotas e Rio Grande, ao norte, com Passo Fundo, e à fronteira, com Bagé, Uruguaiana e Itaqui.

Quanto ao ano de nascimento, o trabalhador mais velho nasceu em 1875 e solicitou sua carteira aos 60 anos, no ano de 1935 (último da Figura 8). Já o mais novo nasceu em dezembro de 1924 e fez o pedido em março de 1941, quando tinha 16 anos (último da Figura 5). Dos 62 trabalhadores com marcas de varíola, 19 nasceram no século XIX, 21 na primeira década do século XX e 22 na segunda década do século XX. Idades variadas podem também indicar que o acometimento sofrido por eles ocorreu em lugares distantes e em anos diferentes.

Surtos epidêmicos de varíola aconteceram no Brasil praticamente desde a chegada dos portugueses (Schatzmayr, 2001), e os dados aqui apresentados demonstram que a doença continuou se disseminando, no caso específico do Rio Grande do Sul, nas últimas décadas do século XIX e nas duas primeiras do século XX. Em outras palavras, as variadas cidades e datas de nascimento demonstram que a doença espalhou-se pelo estado - e provavelmente pelo Brasil - em surtos contínuos, pelo menos até os anos 1940, matando os doentes ou, então, deixando marcas nos sobreviventes. Os trabalhadores retratados no formato $3 \times 4$ constituem, portanto, uma parcela do impacto dessa doença no sul do Brasil. Tais fotografias demonstram os resultados deixados pela doença no rosto do trabalhador e representam um conjunto de imagens da varíola, provavelmente os únicos registros que remetem a momentos distintos em que ocorreram as epidemias.

\section{Considerações finais}

A varíola foi uma doença grave e severa. Aqueles que sobreviviam a ela ficavam com marcas ou cicatrizes irreversíveis. Neste artigo se trabalhou com alguns dados e com um conjunto 
de fotografias $3 \times 4$ de pessoas que resistiram a essa enfermidade, todas residentes no estado do Rio Grande do Sul, e que, em determinado momento de suas vidas, entre 1933 e 1944, solicitaram carteira profissional de trabalho.

Um dos campos da ficha permite registrar os sinais particulares do requerente, o ponto de partida para o desenvolvimento deste texto. Analisando o campo "sinal particular" da ficha e estabelecendo uma comparação entre o que foi nele registrado e a fotografia do trabalhador, foi possível apontar que nem sempre os sinais de varíola estavam nítidos no rosto do fotografado. Entretanto, algumas imagens não deixavam dúvidas em relação às consequências provocadas pela doença, como exemplificam as fotografias das Figuras 6 e 7 . Outro ponto importante foi que os sinais descritos por "bexiga" ou seu derivado "bichigosa" nem sempre eram mais visíveis do que outros descritos pela palavra "varíola". As fotografias dos trabalhadores da Figura 8 confirmam essa consideração.

Ao analisar o conjunto das fotografias $3 \times 4$ desses trabalhadores marcados pela varíola, notou-se que o seu pequeno formato e a maneira como eram feitos os registros, ou seja, valorizando o rosto do fotografado, possuem uma relação com outras produções fotográficas, notadamente, os estudos nos campos jurídico e médico realizados na Europa no século XIX, sem esquecer do álbum fotográfico da casa de correção de Porto Alegre, datado de 1897. Tais fotografias, suas reproduções, a difusão das técnicas fotográficas e as formas como os prisioneiros e doentes eram fotografados - face/perfil - contribuíram para aprimorar os registros oficiais e a confecção de documentos. A carteira profissional foi um deles, e a fotografia do trabalhador, além de ser indispensável à solicitação do documento, também colaborou com a política varguista, em curso nos anos 1930, de controle do Estado, de vigilância da massa de trabalhadores.

Uma interrogação ainda permanece ao final deste texto: será que o uso da expressão "bexiga", ou "bichigosa", para identificar o sobrevivente da varíola, era uma forma pejorativa? Por um lado, a resposta pode ser "sim", se empregada, por exemplo, para desacreditar um inimigo. A resposta também será positiva se forem levados em consideração os autores de determinadas obras literárias - em especial aqueles que conviveram com a doença antes da sua erradicação - que usavam a varíola para castigar suas personagens. Por outro lado, a resposta pode ser "não", ou seja, a denominação referia-se apenas ao formato das cicatrizes e seu emprego foi habitual. No caso das fotografias dos trabalhadores, não é possível afirmar que se tratava de uma forma pejorativa. É uma hipótese plausível que a doença fosse conhecida somente pelo nome oficial "varíola" ou somente pelo adjetivo "bexiga" por pessoas diferentes, em tempos e locais diversos.

Os dados dos trabalhadores que foram vitimados pela varíola, em destaque as suas fotografias, demonstram apenas uma das possibilidades de pesquisa entre diversas outras proporcionadas pelo acervo da DRT-RS. O conjunto dos trabalhadores pesquisados neste texto desenvolvia atividades laborais diversificadas, e as cicatrizes deixadas pela doença marcaram para sempre as suas vidas; no entanto, não impediram sua colocação no mercado de trabalho e a busca por direitos trabalhistas. 


\section{NOTAS}

${ }^{1}$ A pesquisa realizada com os dados das fichas do acervo da DRT-RS foi facilitada pela criação de um banco de dados que reproduz todos os campos da ficha. A partir desse banco é possível cruzar as informações e estabelecer perfis de trabalhadores de acordo com as intenções de pesquisa. Dessa forma, cruzando os dados, é possível analisar um grupo específico de trabalhadores que solicitaram a sua carteira profissional entre os anos de 1933 e 1944, os quais correspondem aos anos que já foram digitados no banco. A consulta ao banco de dados partiu das palavras "varíola" e "bexiga", e foram encontrados 62 trabalhadores identificados com a doença. Contudo, à medida que a digitação e a pesquisa avancem, é possível que o número de trabalhadores com esses sinais particulares se amplie. Da mesma forma, é importante ressaltar que se trata apenas dos trabalhadores que tiveram a doença e solicitaram a carteira profissional; em outras palavras, possivelmente o número de trabalhadores marcados pela doença, no estado do Rio Grande do Sul, foi maior do que aquele registrado nos dados da DRT.

${ }^{2}$ Nesta e nas demais citações de textos em outros idiomas, a tradução é livre.

${ }^{3}$ Outros importantes exemplos de referências à varíola no universo literário são as obras Ligações perigosas, do escritor francês Choderlos de Laclos (2008), Teresa Batista cansada de guerra e Capitães da areia, ambas do escritor brasileiro Jorge Amado (2008, 1996).

${ }^{4}$ Conforme aponta Hermann G. Schatzmayr (2001, p.1526), "no Brasil, a varíola foi referida pela primeira vez em 1563, na ilha de Itaparica, na Bahia, disseminando-se para Salvador e causando grande número de casos e óbitos, principalmente entre os indígenas".

${ }^{5}$ As primeiras vacinas começaram a ser testadas no final do século XVIII, e a doença foi erradicada nos anos 1970, sendo os últimos focos registrados no continente africano. Em 1980, a Organização Mundial da Saúde anunciou a erradicação da varíola (Quaresma, 2012, p.44).

${ }^{6}$ Determinados trabalhadores foram importantes lideranças sindicais e se destacaram dos demais escrevendo em jornais, por exemplo, o que possibilitou o desenvolvimento de trabalhos biográficos. Essa não é a situação dos trabalhadores pesquisados no acervo da DRT-RS, como um todo, nem mesmo do grupo identificado com a varíola, em específico. Um exemplo de biografia de trabalhadores é a tese de Benito Schmidt, publicada em livro (Schmidt, 2004).

\section{REFERÊNCIAS}

AMADO, Jorge.

Teresa Batista cansada de guerra. São Paulo: Companhia das Letras. 2008.

AMADO, Jorge.

Capitães da areia. Rio de Janeiro: Record. 1996.

ASSIS, Machado de.

Memórias póstumas de Brás Cubas. Barcelona: Editorial Sol 90. 2004.

BRASIL.

Decreto n.21.580, de 29 de junho de 1932 . Altera e regulamenta o decreto n.21.175, de 21 de março de 1932, que institui a carteira profissional. Disponível em: https://www. planalto.gov.br/ccivil_03/decreto/1930-1949/ D21580impressao.htm. Acesso em: 21 set. 2013. 29 jun. 1932.

CHAMBOULEYRON, Rafael et al.

"Formidável contágio": epidemias, trabalho e recrutamento na Amazônia colonial (1660-1750). História, Ciências, Saúde - Manguinhos, v.18, n.4, p.987-1004. Disponível em: http://www.scielo. br/scielo.php?script=sci_arttext\&pid=S0104$59702011000400002 \& \operatorname{lng}=$ pt\&nrm=iso. Acesso em: 24 set. 2014. 2011.
DUBOIS, Philippe.

$O$ ato fotográfico e outros ensaios. Campinas: Papirus. 1993.

DIDI-HUBERMAN, Georges. Invention of hysteria: Charcot and the photographic iconography of the Salpêtrière. Massachusetts: The MIT Press. 2003.

FABRIS, Annateresa.

Fotografia e arredores. Florianópolis: Letras Contemporâneas. 2009.

FABRIS, Annateresa (Org.).

Fotografia: usos e funções no século XIX. São Paulo: Edusp. 2008.

FABRIS, Annateresa.

Identidades virtuais: uma leitura do retrato fotográfico. Belo Horizonte: Ed. UFMG. 2004.

FEE.

Fundação de Economia e Estatística. De província de São Pedro a estado do Rio Grande do Sul: censos do RS - 1803-1950. Porto Alegre: FEE-RS. 1981.

FRANCO, Sérgio da Costa.

Júlio de Castilhos e sua época. Porto Alegre: Ed. UFRGS. 1996. 
FRENCH, John D.

Afogados em leis: a CLT e a cultura política dos trabalhadores brasileiros. São Paulo: Perseu Abramo. 2001.

GOMES, Angela de Castro.

A invenção do trabalhismo. Rio de Janeiro: Iuperj. 1988.

HOCHMAN, Gilberto; MELLO, Maria Teresa Bandeira de; SANTOS, Paulo Roberto Elian dos. A malária em foto: imagens de campanhas e ações no Brasil da primeira metade do século XX. História, Ciências, Saúde - Manguinhos, v.9, supl., p.233-273. Disponível em: http://www.scielo. br/scielo.php?script=sci_arttext\&pid=S010459702002000400011\&lng=pt\&nrm=iso. Acesso em: 30 nov. 2015. 2002.

KOSSOY, Boris.

Fotografia e história. São Paulo: Ateliê Editorial. 2012.

KOUTSOUKOS, Sandra.

Negros no estúdio do fotógrafo: Brasil, segunda metade do século XIX. Campinas: Ed. Unicamp. 2010.

LACERDA, Aline Lopes de.

Retratos do Brasil: uma coleção do Rockefeller Archive Center. História, Ciências, Saúde Manguinhos, v.9, n.3, p.625-645. Disponível em: http://www.scielo.br/scielo.php?script=sci arttext\&pid=S0104-59702002000300008\&lng= pt\&nrm=iso\&tlng=pt. Acesso em: 30 nov. 2015 . 2002.

LACLOS, Choderlos de.

Ligações perigosas. Porto Alegre: L\&PM. 2008.

LONER, Beatriz.

O acervo sobre trabalho do Núcleo de

Documentação Histórica da UFPel. In: Schmidt, Benito (Org.). Trabalho, justiça e direitos no Brasil: pesquisa histórica e preservação das fontes. São Leopoldo: Oikos. p.9-24. 2010.

LONER, Beatriz.

Um perfil do trabalhador gaúcho na década de 30. In: Encontro Estadual de História da AnpuhRS, 9., 2008, Porto Alegre: Anais... Porto Alegre: Anpuh-RS; UFRGS. p.1-18. Disponível em: http:// eeh2008.anpuh-rs.org.br/site/anaiseletronicos\#C. Acesso em: 8 nov. 2015. 2008.

MACHADO, Carlos Gonçalves.

Varíola. In: Amato Neto, Vicente; Baldy, José Luís da Silveira. Doenças transmissíveis. São Paulo: Sarvier. 1989.
MAUAD, Ana Maria.

Poses e flagrantes: ensaios sobre história e fotografias. Niterói: Ed. UFF. 2008.

MELLO, Maria Teresa Bandeira de; PIRES-ALVES, Fernando A.

Expedições científicas, fotografia e intenção documentária: as viagens do Instituto Oswaldo Cruz (1911-1913). História, Ciências, SaúdeManguinhos, v.16, supl.1, p.139-179. Disponível em: http://www.scielo.br/scielo.php?script=sci arttext\&pid=S0104-59702009000500008\&lng= pt\&nrm=iso\&tlng=pt. Acesso em: 30 nov. 2015. 2009.

PESAVENTO, Sandra.

Visões do cárcere. Porto Alegre: Zouk. 2009.

QUARESMA, Paulo S.

Urbe em tempos de varíola: a cidade do Rio Grande (RS) durante a epidemia de 19041905. Dissertação (Mestrado em História) Universidade Federal de Pelotas, Pelotas. 2012.

ROUILLÉ, André.

A fotografia entre documento e arte contemporânea. São Paulo: Editora do Senac São Paulo. 2009.

SCHATZMAYR, Hermann G.

A varíola, uma antiga inimiga. Cadernos de Saúde Pública, v.17, n.6, p.1525-1530. Disponível em: http://www.scielo.br/scielo.php?script=sci arttext\&pid=S0102-311X2001000600037\&lng=e n\&nrm=iso. Acesso em: 25 set. 2014. 2001.

SCHMIDT, Benito.

Em busca da terra da promissão: a história de dois líderes socialistas. Porto Alegre: Palmarinca. 2004.

SCHNEIDER, Silvia Danielle.

Lepra: fotografia e discurso na obra de SouzaAraújo (1916-1959). Dissertação (Mestrado em História) - Universidade Estadual do Oeste do Paraná, Marechal Cândido Rondon. 2011.

SILVA, James Roberto.

Doença, fotografia e representação: revistas médicas em São Paulo e Paris, 1869-1925. Tese (Doutorado em História Social) - Universidade de São Paulo, São Paulo. 2003.

TAGG, John.

The burden of representation: essays on photographies and histories. New York: Palgrave Macmillan. 2002.

ZOLA, Émile.

Naná. São Paulo: Círculo do Livro. 1982. 


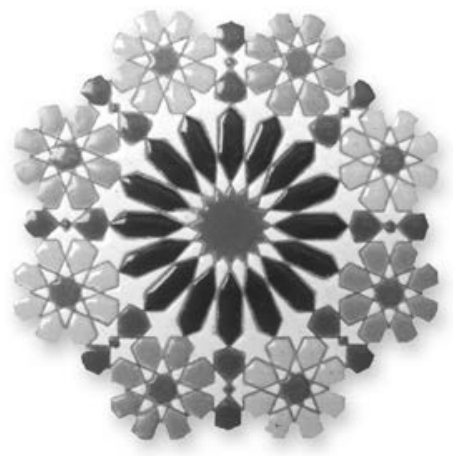

